\title{
Invasive mole
}

\author{
INSERM
}

\section{Source}

INSERM. (1999). Orphanet: an online rare disease and orphan drug data base. Invasive mole. ORPHA:99925

An invasive mole is a gestational trophoblastic tumor (GTT; see this term) derived from a hydatidiform mole (see this term) extending into the myometrium. 